\title{
The Formation of Minangkabau Language Absorption Elements in Enriching the Indonesian Language
}

\author{
Elvina A. Saibi and Puspawati \\ Universitas Bung Hatta Padang
}

\section{Abstract}

The word absorption in the Indonesian language is a word that comes from the local language and foreign language and the way of writing where there is a change in the in it or vice versa. One of the elements of the uptake of regional languages in the Indonesian language comes from Minangkabau language. The contribution of the Minangkabau language vocabulary in the Indonesian language occurs in its entirety and some adjustments. The vocabulary of the Minangkabau language in the Huge

Corresponding Author:

Elvina A. Saibi

elvinaasaibi@gmail.com

Received: 18 January 2019

Accepted: 24 March 2019

Published: 31 March 2019

Publishing services provided by

Knowledge E

(c) Elvina A. Saibi and

Puspawati. This article is

distributed under the terms of

the Creative Commons

Attribution License, which

permits unrestricted use and

redistribution provided that the

original author and source are

credited.

Selection and Peer-review under the responsibility of the First ELEHIC Conference Committee. Indonesian Dictionary (KBBI) is, among others, absorbed in the formation of sound changes that are easily recognized by the user community, such as phoneme changes in the word rangkik in Minangkabu language (BM) changed into the word rengkit in Indonesian language (BI) 'weary', dunsanak (BM) becomes dansanak (BI) 'relatives'; the removal of the phoneme coga (BM) becomes cogah (BI), dia (BM) becomes diar (BI) 'let', there is also a fully absorbed BM element, such as bacak (BM) to bacak (BI) 'freckled' muno (BM) becomes muno (BI) 'lost memory'. The policy of the relationship between Indonesian and local languages in order to make Indonesian people can put precisely the position and function of Indonesian language and regional languages in bilingual situation.

Keywords: absorption element, Minangkabau language, Indonesian language

\section{Background}

Bahasa Indonesia is the unity language of Indonesian nation as implied in the Youth Pledge of October 28th, 1928, the language of the country as mentioned in the 1945 Constitution, article 36 which, from the point of language structure, is the variety of Malay language or as it was stipulated in the Indonesian II Congress of 1954 in Medan, The Basics of Indonesia is a Speeding Language adapted to the growth of the Indonesian society ". Chaer [1] reveals in its development, Indonesian language absorb many elements of regional languages and elements of foreign languages. 
One of the development of Indonesian languages comes from elements of regional languages that have enriched the Indonesian language in perkembanggnnya, especially in terms of his vocabulary. Not a few local languages are picked up and then become an Indonesian word [2], then the number of Indonesian vocabulary increasing one of which comes from the Minangkabau language. The Indonesian vocabulary (BI) is not only accepting the richness of the local languages, but now there should be a vocabulary of local language sources that could potentially be developed as Indonesian riches. It can be proved that in the Big Indonesian Dictionary (KBBI) the existence of Minangkabau (BM) language vocabulary is largely absorption element of indonesian. Based on the writer's observation, the amount of absorption element of BM in $\mathrm{Bl}$ contained in Huge Indonesian Dictionary Second Edition [3] amounted to 455 vocabulary.

The research of absorption element of BM in BI by the author's knowledge has never been done. This study examines the formation of Minangkabau language absorption elements in Indonesian language. In this study the authors observed the process of formation of absorption elements of BM in BI.

\section{Methodology and Theory}

According to Chaer [4] word absorption is a word that comes from a foreign language or regional language, then used in the Indonesian language. Furthermore, Chaer states that from tarap absorption there are three kinds of absorption words, namely (1) words that have been fully absorbed into the Indonesian language, so it is no longer felt its presence as an absorption word, for example, soursop, advertisement, body. (2) Words that are still foreign, but used in the Indonesian context. Spelling and pronunciation still follow the alien way, for example cock, time out, check in, door to door. (3) Foreign words which for the purposes of terminology, speech and spelling are adapted to Indonesian rules. In this case the change of spelling is made as necessary so that its Indonesian form can still be compared with the original form of the language, such as battery (accu), commission (commission), and phase (phase).

The formation of the absorption element of $\mathrm{BM}$ in $\mathrm{Bl}$ used Chaer approach [4] about sound changes as a result of morphological process called morphophonemic or morphophonology. In this process it may occur the events of (a) the appearance of phonemes, (b) phonemic releasing, (c) phoneme delivery, (d) phoneme shifts, and (e) phoneme changes. (f) phoneme perpetual. Furthermore, to understand the syllable [4] is the smallest rhythmic unit in a speech current. A syllable usually involves one vowel sound or one vowel and one or more consonants. The sequence of consonant-vowel 
sounds in a syllable is called phonotactic. The consonant sound before the vowel (which is the peak of its loudness) is called the onset $(\mathrm{O})$ and the consonant present after the vowel is called the koda $(\mathrm{K})$ while the vowel itself is called the nuklus $(\mathrm{N})$, for example the Indonesian word eating (makan) the syllable is ma-kan but for the word food,the syllable is ma-ka-nan. The sound / $\mathrm{n} /$ which becomes the koda $(\mathrm{K})$ in the syllable in the word kan is replaced to an onset $(\mathrm{O})$ on the syllable of nan from the word food. Orthographically, the Indonesian spelling provisions is ma-kan-an, but orthographically labeled ma-ka-nan.

The method used is descriptive method. Source of data obtained from MinangkabauIndonesia Dictionary Language [5] and Kamus Besar Bahasa Indonesia (Second Edition) [3]. The method of data provision is done by referring method [6], for example listening to BM vocabulary in BM dictionary and BI dictionary then use the technique of record, the data collected done recording on the data card which immediately followed by the classification data. The method of data analysis is used by the method of agih tool is precisely part of the language in question [6] and data analysis technique used technique of lesap, change technique.

\section{Results and Discussions}

\subsection{The appearing and changing of phoneme BMBI}

The appearance of the phoneme of the absorption element of BM in $\mathrm{BI}$ (BMBI) occurs because of the presence of a phoneme which was not present because of the morphological process arises a phoneme in the morphophonemic at the beginning, middle, and end of the word in the following data:

\section{1. andam - handam}

In the formation of the Indonesian word absorption element andam into handam (BI) 'memingit'(stay at home) only one data encountered its appearance at the beginning of the word data (1) there is no previous morphophonemic process appear consonant fricative glottal / h / as onset $(O)$ if its basic form starting with the vowel / a / in the first syllable an of the word andam becomes han from word handam. Furthermore, BMBI phonemes appear in the middle of the word in the following data:
2. botok - bontak
3. saok - sahap 
The absorption element of BMBI data (2) botok becomes bontak 'round bulb' it appear bo to bon on the first syllable consonant / $\mathrm{n}$ / as the koda emerges when the basic form begins with consonant / b / botok becomes bontak as well as vocal changes / o / on the second syllable becomes the vowel / a / followed by the consonant / k /. Data (3) soak if the basic form begins with the consonant / s / becomes a sahap 'cover' phenomenon occurs the appearance of consonant / $\mathrm{h} /$ as onset in the second syllable if the second syllable begins with vowel / o / becomes consonant / h / accompanied by vowel / o / being vowel / a / and consonant / k / being consonant / $\mathrm{p} /$. In addition, there are phonemic appearances and changes at the end of the following words:
4. dia - diar
11. jolo - jolor
5. baga - bagar
12. sarawa - serawal
6. dama - damar
13. gawa - gawal
7. kaca - kacar
14. coga - cogah
8. pasa - pasar
15. ungka - ungkah
9. sanga - sangar
16. tungkah - tungkahan
10. ponda - pondar

In the data (4-10) the pattern of consonant appearance / $r$ in dia, baga, dama, kaca, pasa, sanga, ponda becomes diar let go, bagar 'gulai bagar', damar 'candlenut', kacar 'grope', pasar 'slippery', sangar 'stimulating like the smell of union, dan pondar 'dumpy' occurs when the second syllable basic word begins with a, ga, ma, ca, sa, nga, and da to be ar, gar, mar, car, sar, ngar, and dar, the appearance of phoneme /r/ in (BI) as koda besides (11) the word jolo becomes jolor 'creep' occurs when the second syllable begins with the consonant / / / lo becomes lor, consonant / r / as the code. The data (12) and (13) the sarawa becomes the sarawal 'pants' and gawa become gawal, the consonant / I / as the koda arises when the basic form in the third syllable begins with wa becomes wal while the data 14 and 15 coga becomes cogah 'dashing', and ungka become the ungkah 'dismantle' the appearance of those consonants / $\mathrm{h} /$ as koda when the second syllable begins with ga and ka become gah and kah. In addition, the data (16) tungkah becomes tungkahan 'foundation' when the basic word tungkah, second syllable kah ends up with the consonant / $\mathrm{h} /$ as the koda gets affixed-an the third syllable where it becomes the onset of the third syllable han on the word tungkahan (BI). 


\subsection{Releasing and changing phoneme $\mathrm{BMBI}$}

The absorption of phoneme $\mathrm{BM}$ in $\mathrm{Bl}$ is an event of phoneme loss due to morphological process. The phonemic absorption element of $\mathrm{BM}$ in $\mathrm{Bl}$ is found in the following data:

17. kalikih - keliki

18. sunuah - sunu

In the data (17) there is consonant deletion / h / as the koda on the third syllable kih word kalikih becomes keliki 'papaya fruit'. The data (18) of sunuah into sunu 'burn' occurs consonant deletion / $\mathrm{h} /$ as the koda on the second syllable of nuah to nu with the change of diphthong / ua / to be / u /. Both data are imprinted on the second syllable ending with consonant / h /.

\subsection{Changing phoneme $\mathrm{BMBI}$}

The changing phoneme $\mathrm{BM}$ in $\mathrm{BI}(\mathrm{BMBI})$, that is the changing of a phoneme into another form of phoneme in the following data:
19. kuia - kuir
22. kincia - kincir
20. alia - alir
23. lansia - langsir
21. gabia - gabir

The change of data phonemes (19-23) kuia become kuir 'peasant', alia becomes alir 'slippery', gabia becomes gabir 'unusual', kincia becomes kincir 'jentera', and elderly becomes langsir 'skinny'. The phoneme change of each data occurs when the second syllable ends with diphthong / ia / as the nuklus becomes ir (BI) vowel / i / with the consonant / r / (BI) as the koda and begins phoneme / / /, / b / / c/, and / s /, except the data kuia becomes kuir direct diphthong / ia / to be ir followed by consonant as the nuklus becomes koda.
24. atua - atur
27. ganjua - ganjur
25. takua - takur
28. julua - julur
26. sumbua - sumbur

The data phoneme change (24-28) occurs in the second syllable of diphthong / ua / becomes / ur / second syllable beginning with the phoneme / t/, / k /, / b /, / j/, and / I / (BMBI) atua becomes atur 'set', takua becomes takur 'submissive', sumbua becomes sumbur 'fertilize', ganjua becomes ganjur 'pull', and julua becomes julur 'creep'. The 
changing occurs in the second syllable diphthong / ua / as nuklus turns into / ur /, vowel / $\mathrm{u}$ / accompanied by the consonant / $\mathrm{r}$ / as the koda. Other phoneme changes as follows:
29. paguik - pagut
34. runyuik - runyut
30. lacuik - lacut
35. kambuik - kembut
31. ruruik - rurut
36. lingkuik - lingkup
32. unjuik - unjut
37. culiak - colek
33. conguik - cengut

Furthermore, phoneme changes occur in BMBI (29-35) data when the second and third syllables are preceded by the phoneme $/ \mathrm{g} / \mathrm{l} / \mathrm{c} / \mathrm{L} / \mathrm{r} / \mathrm{l} / \mathrm{j} / \mathrm{/} / \mathrm{ng} /$, ny $/$, and / b / second syllable word ends with uik to be ut, diphthong / ui / being vocal / u / accompanied by consonant / k / (BI) remains as a koda on the word paguik becomes pagut 'hug', Iucuik becomes lucutt 'hit', ruruik becomes rurut 'fall', unjuik becomes unjut 'handkerchief', conguik becomes cengut 'stunned', runyuik becomea runyut 'wrinkled', kambuik becones kembut 'woven pouch', except (36) and (37) the lingkuik becomes lingkup 'go or come all", diphthong / ui / being vowel / u / accompanied by consonant / p / on the second syllable of kuik into kup and culiak becomes colek 'poking', the syllables of the two liak end up being iak to be ek a syllable of lek and culiak becomes colek, the change in the first syllable of the cu vowel / $\mathrm{u} /$ becomes co vowel / o / beginning consonant / c / and diphthong / ia / becomes vowel / e / second syllable followed by consonant / $\mathrm{k} /$. The phonemic changes of BMBI absorption elements also occur in the following data:
38. dabiah - dabih
44. labuah - lebuh
39. siriah - sirih
45. uduah - uduh
40. sangiah - sangih
46. guguah - guguh
41. suntiah - suntih
47. lasuah - lasuh
42. Iapiah - lapir
48. kuyuah - kuyuh
43. kampuah - kempuh
49. lintuah - lintuh

The phoneme change of BMBI data (38-42) occurs a change of diphthong / ia / with consonant / $\mathrm{h} / \mathrm{iah}$ becomes vowel / $\mathrm{i} /$ accompanied by second syllable / $\mathrm{h} / \mathrm{ih}$ as nuklus if begins with phonem /b/, /rl, /ng/, / t / biah from word dabiah, riah from word siriah, ngiah from word sangiah, and piah from word lapiah become bih word dabih 'slaughtered', rih word sirih 'plant', ngih word sangih 'glut', tih word suntih 'cutting the meat', except lapiah, syllable iah become ir to be lapir 'interwoven tightly'. However, (43-49) the changing at 
the end of the second syllable becomes $u h$ vowel / $\mathrm{u} /$ accompanied by the consonant / $\mathrm{h}$ / as nuklus with the starting point of the phoneme / p/,/ b/,/ d/,/ g. / s/, / y /, and / t / in the second syllable of the word kampuah, labuah, uduah, kesuah, lasuah, kuyuah, lintuah become kempuk 'soft' 'peluk', lebuh jalan 'big', uduh 'medicinal herb', guguh 'hit', lasuh 'fluent', kuyuh 'pee', lintuh 'weak'. The next variation of phoneme changes as follows:
50. loroang - lorong
54. cangguang - canggung
51. joloang - jolong
55. santuang - sentung
52. saluang - salung
56. sunggiang - sungging
53. garuang - garung

Data (50) and (51) there are a change of diphthong / oa / become vowel / o / with consonant / ng / as nuklus in the second syllable of roang and loang beginning by consonant / $r$ / and / / / in the words lorong 'about' and jolong 'beginning'. The data (52$55)$ the second syllable change in the second word luang to the word saluang becomes lung, the word salung 'flute' flute, ruang from word garuang to be rung, the word garung 'hard cry', the word guang the word cangguang becomes gung the word canggung 'awkward', and tuang the word santuang into tung the word santung 'tight', diphthong / ua / being vowel / $\mathrm{u}$ / accompanied by consonant / ng / as nuklus with starting point by consonant $/ \mathrm{I} / \mathrm{l} / \mathrm{r} / \mathrm{l} / \mathrm{g} /$, and $/ \mathrm{t} / \mathrm{l}$ In addition, there is a change in the syllable of san to sen, vowel / a / being vocal / e / data (55), except (56) sunggiang becomes sungging 'bulge toward the bottom', the change occurs in the second syllable diphthong / ia / giang becomes vocal / $\mathrm{i}$ / ging beginning with consonant / $\mathrm{g} /$. Other phoneme changes can also be observed in the following data:
57. karopoih - kerepas
61. dabiah - dabih
58. indaruih - indarus
62. sangiah - sangih
59. kacimuih - kacimus
63. bangih - bengis
60. tampuih - tampus
64. kikih - kikis

Data (57) BMBI happens the changes the word karopoih the first syllable ka becomes $k e$, ro the second term becomes re, and poih becomes pas the third syllable of the phrase which begins consonant / $\mathrm{p} /$ in karopoih word becomes kerepas 'broke' while the data (58-60) change of final syllable uih that begins consonant / d /, / c /, and / p I from the word indaruih, kacimuih, and tampuih to be us word indarus 'cock fighting', kacimus 'mock', and tampus 'yellow reddish', diphthong / ui / accompanied by consonant / h / being / u / accompanied by consonant / s / preceded by consonant / r /, / m /, / p 
/, / b /, / ng /. However, the data (61) became dabiah to be dabih 'slaughtered' and(62) sangiah become sangih 'glut,' the changing occurs in the syllable bangih end with iah that begins consonant / b / and / ng / in biah syllable and ngiah syllable and become bih and ngih into ngis that begins consonant / ng / as the nuklus. The data 63 and 64 bangih to be bengis 'angry' and kikih becomes kikis 'run out', the changing occurs in the second consonant / h / syllable in ngih syllable to be ngis and first syllable ba vowel / a / becomes be vowel / e / as a nuklus. Subsequent data changes are in the following vowels and consonants below:
65. racak - recak
70. saro - sara
66. rado - reda
71. tundo - tunda
67. salang - selang
72. tiago - tiaga
68. dunsanak - dansanak
;73. kalubik - kalubak
69. sako - saka
74. babatok - babotok

The data 65 and 66 are voweled / a / become vowel / e / in the first syllable of ra word racak to be re to the word recak 'sitting astride on horse' as nuklus begins by the consonant / $\mathrm{r} /$ the word rado becomes reda 'almost stopped' begins consonant / $\mathrm{d} /$ occurs on the second syllable do to be da. Data (67) salang becomes selang 'borrow' nuklus interval of vowel change / a / into vowel / e / lies in the first syllable of si into se as the nuklus begins by consonant / s /. Data (68) dunsanak become dansanak 'relatives' vocal changes / u / becomes vowels / a / in the first syllable dun and dan as nuklus witht the starting point consonant / d /. The data (69-72) sako becomes saka 'mother's family', saro being sara 'asks for consideration', tundo becomes tunda 'something is pulled behind the boat with a rope', tiago becomes tiaga 'commerce', changing occurs on vowel / o / being the vowel / a / the second syllable becomes ko to be ka, ro becomes ra, do become da, go becomes ga in the third syllable as nuklus a starting point by consonant / k /, / r /, / d /, / g /. The data (73) of the kalubik becomes kalubak 'peeled', the third syllable bik becomes bak which beginning with the consonant / b / and vowel changes / i / to be vowel / a / as the nuklus and consonant / k / (74) babatok becomes babotok, vocal changes / a / becomes vowel / o / on second syllable as the nuklus. Furthermore, vowel and consonant changes in the following data:
75. kulimek - kulimat
81. singkop - singkak
76. kabek - kabat
82. ulik - ulit
77. cangok - cangap
83. garik - garit
78. jajok - jejap
84. radang - redut 
79. lindok - lindap 85. sikek - sisir

80. tangek - tangap

86. gasan - gasang

Data (75) and (76) there is a change of vowel / e / become / a / as nuklus with consonant / k / being consonant / $\mathrm{t}$ / as the koda on the third syllable mek from the word kulimek becomes mat the word kulimat 'frugality' and the second syllable bek the word kabek to be bat kabat 'kin/tie' each words starting by the consonant / m / and / b /. The data (7779) the second syllable ngok word cangok, jok word jajok, dok word lindok becomes ngap word cangap 'greedy', jap word jejap 'disguise', dap word lindap 'dim', changes occur in vocals / o / accompanied the consonant / k / being / a / accompanied by the second consonant / $\mathrm{p} /$ syllable ending with the ok being changed to ap as the koda starting with the consonant / $\mathrm{ng} / \mathrm{,} \mathrm{/} \mathrm{j} \mathrm{/,} \mathrm{/} \mathrm{d} \mathrm{/} \mathrm{but} \mathrm{the} \mathrm{data} \mathrm{(80),} \mathrm{the} \mathrm{change} \mathrm{occurs} \mathrm{on} \mathrm{the}$ second syllable tangek becomes tanggap 'holding' changes happen to second syllable ngek into ngap as koda, vowel / e / accompanied by consonant / k / becomes vowel / a / accompanied by consonant / p /, except (81) singkop becomes singkak 'singkap', the syllable of kop becomes kak a change takes place in the nuklus and the koda on the syllable ending op into $a k$. The data (82) and (88) ulik and garik become ulit 'do not want to pay debts' and garit 'movement', changes occur when the syllables of lik and rik change into lit and rit syllables beginning with consonant / I/, and / r/. The changes of ulik turns to ulit occur on consonant / $\mathrm{k}$ / becomes consonant / $\mathrm{t} /$ as koda. The data (84) radang becomes redut 'irritated' change in the first syllable ra of vowel / a / to re vowel / e / as the second syllable and dang becomes dut as the nuklis and koda, only consonant / d / unchanged. The data 85 sikek turns into sisir 'insert', the total change of kek and sir as ONK (onset, nuklus, and koda) and data 86 gasan into gasang 'hasty', the second syllable change beginning by the consonant / s / san consonant / $\mathrm{n}$ / being sang / ng / as koda.

\subsection{Perpetual phoneme BMBI}

Perpetual phoneme occurs when the underlying form is not complete and does not change in the following data.
87. awai - awai
91. jangkang - jangkang
88. balun - balun
92. kuyu - kuyu
89. cilok - cilok
93. Ialah - Ialah

90. dongkak - dongkak

94. rasan - rasan 
In the data (87-94) there are some BMBI phoneme consolidation data representing data on the absorption element of BMBI. The data is unchanged and the meaning in $\mathrm{BI}$ awai 'holding', balun 'rolling', cilok 'stealing', dongkak 'crashing', jangkang 'dead', kuyu 'timid', lalah 'chasing', and rasan 'stale' '.

\section{Conclusions and Suggestions}

Based on the discussion in the process of formation of Minangkabau language absorption element in Indonesian language can be concluded that there are four types of morphophonemic formation, namely the appearance and changes of phonemes, phonemic changes and changes, phoneme changes, and phoneme pengekalan. Based on the pattern (1) the appearance and phoneme changes vary, as the consonant / $\mathrm{h} /$ appears at the beginning of the syllable with the vowel / o / vowel / a /; appearance of consonant / $\mathrm{n} /$ and / h / in the middle of syllable with vowel change / o / being / a /; and the appearance of the vowel / a / to / ar / at the end of the syllable with the vowel / a / and vowel / e / changes in the first syllable. (2) releasing consonant / h / at the end of syllable accompanied by change of diphthong / ua / into vowel / u /. (3) The final change of syllable is in / ia / becomes / ir /; / ua / being / ur /; / uik / being / ut /; / iak / being / ek / (except); / iah / be / ih /; / uah / being / uh /; / oang / being / ong /; / money / being / ung /; iang being / ing /; / oih / being / as /; / uih / being / us /; / iah / be / ih /; / ih / being / is /. (4) Phoneme consolidation in the absorption element of BMBI does not occur deletion, appearance, or phoneme changes. This research needs to be continued in morphology and syntax studies.

\section{References}

[1] Chaer, A. (1993). Pembakuan Bahasa Indonesia. Jakarta: Rineka Cipta

[2] Badudu, J.S. (1993). Cakrawala Bahasa Indonesia I. Jakarta: Gramedia Pustaka Utama

[3] Tim Penyusun Kamus Besar Bahasa Indonesia Pusat Pembinaan dan Pengembangan Bahasa Departemen Pendidikan dan Kebudayaan. (1996). Jakarta: Balai Pustaka

[4] Chaer, A. (2009). Fonologi Bahasa Indonesia. Jakarta: Rineka Cipta

[5] Tim Penyusun Kamus Bahasa Minangkabau-Indonesia Balai Bahasa Padang Pembinaan dan Badan Pembinaan dan Pengembangan Bahasa Kementerian Pendidikan dan Kebudayaan. (2012). Jakarta: Balai Pustaka 
[6] Sudaryanto. (2015). Metode dan Aneka Teknik Analisis Bahasa. Jakarta: Sanata Dharma University press 